\title{
1 Factors influencing the recession rate of Niagara Falls since the 19th century
}

2 Yuichi S. Hayakawa ${ }^{a, *}$ and Yukinori Matsukura ${ }^{a}$

$3{ }^{a}$ Geoenvironmental Sciences, Life and Environmental Sciences, University of Tsukuba, 1-1-1

4 Ten-nodai, Tsukuba, Ibaraki 305-8572, Japan

5

6

$7 *$ Corresponding author. Tel: +81-29-853-5691; Fax: $+81-29-853-4460$

$8 \quad$ E-mail address: hayakawa@geoenv.tsukuba.ac.jp (Y.S. Hayakawa) 


\section{Abstract}

The rate of recession of Niagara Falls (Horseshoe and American Falls) in northeastern

12 North America has been documented since the 19th century; it shows a decreasing trend from ca.

$131 \mathrm{~m} \mathrm{y}^{-1}$ a century ago to ca. $0.1 \mathrm{~m} \mathrm{y}^{-1}$ at present. Reduction of the flow volume in the Niagara

14 River due to diversion into bypassing hydroelectric schemes has often been taken to be the factor responsible, but other factors such as changes in the waterfall shape could play a role and call for a quantitative study. Here, we examine the effect of physical factors on the historically varying recession rates of Niagara Falls, using an empirical equation which has previously been proposed based on a non-dimensional multiparametric model which incorporates flow volume, waterfall shape and bedrock strength. The changes in recession rates of Niagara Falls in the last century are successfully modeled by this empirical equation; these changes are caused by variations in flow volume and lip length. This result supports the validity of the empirical equation for waterfalls in rivers carrying little transported sediment. Our analysis also suggests that the decrease in the recession rate of Horseshoe Falls is related to both artificial reduction in river discharge and natural increase in waterfall lip length, whereas that of American Falls is solely due to the reduction in flow volume. 


\section{Introduction}

31

Waterfalls, a typical form of knickpoint or knickzone, are commonly observed in bedrock rivers across the world, including active orogens, volcanic areas and glacially- or tectonically-deformed areas (Gilbert, 1907; von Engeln, 1940; Derricourt, 1976; Bishop et al., 2005; Crosby and Whipple, 2006; Hayakawa and Oguchi, 2006, 2009; Lamb et al., 2007). Headward erosion of waterfalls, often referred to as recession, is one of the central themes in fluvial geomorphology because the rates of waterfall recession are usually much greater than the other erosional processes involving bedrock rivers, such as incision of the entire riverbed (Begin et al., 1980; Kukal, 1990; Wohl, 1998, 2000; Hayakawa and Matsukura, 2002). Bedrock erosion at waterfalls can be significant even if rivers lack transported sediment to act as a tool of abrasion, probably due to the frequent occurrence of plucking and/or cavitation by rapid stream flows including jet flows (Barnes, 1956; Young, 1985; Bishop and Goldrich, 1992; Whipple et al., 2000; Pasternack et al., 2006). Niagara Falls is a famous waterfall in northeastern North America that has long been studied by geologists and geomorphologists (Gilbert, 1907; Spencer, 1907; Tinkler, 1987). Historical changes of the waterfall shape are well documented, especially in the last 200 years, and the actual recession rates in that period are well known. The long-term average recession rate of Niagara Falls is estimated to have been ca. $1 \mathrm{~m} \mathrm{y}^{-1}$ during the Holocene (e.g., Gilbert, 1907; Ford, 1968), but it has decreased to the order of $0.1-0.01 \mathrm{~m} \mathrm{y}^{-1}$ in recent decades (Tinkler, 1993). The slowing of the waterfall recession rate is commonly attributed to the reduction in water flow over the waterfall as a result of the construction of several large power plants in the river (e.g., Tinkler, 1993, 1994). These plants divert water well above the falls and return it to the Niagara River well below the falls. The shape of the falls in plan has also changed during the recession process, and the curved shape of the waterfall crest (the 'horseshoe' shape) is supposed to be more stable in its stress distribution and thereby 
decreases the recession rate (Philbrick, 1970). The greater length of the curved lip may also cause the stream to be shallower with less tractive force at the lip, also reducing the recession rate, although the effects of lip length on the recession of Niagara Falls are yet to be quantified. Here we quantitatively examine the recession rate of Niagara Falls based on a previously proposed model, which estimates the waterfall recession rate from relevant physical parameters including the stream discharge (total flow) and waterfall shape.

\section{Existing record of recession rates of Niagara Falls}

Niagara Falls is located in the middle portion of the Niagara River, draining northward from Lake Erie to Lake Ontario (Fig. 1). The water of the Niagara River is supplied from the upstream Great Lakes, of glacial origin, and the stream discharge is controlled mainly by the water level in the lakes, not by immediate precipitation. The climate in the area is relatively cold, with active frost weathering of bare rocks exposed along the river from winter to spring.

The waterfall originally formed at the Niagara Escarpment running west to east between the lakes, when the Laurentide ice sheet had receded and the river started draining over the escarpment approximately 12,500 years ago (Tinkler et al., 1994). Since then the waterfall has receded for ca. $11 \mathrm{~km}$, leaving a deep narrow gorge downstream, called the Great Gorge. The long-term mean recession rate of the waterfall is therefore approximately $1 \mathrm{~m} \mathrm{y}^{-1}$, although the rate was considerably lower for about 5,000 years during 10,500-5,500 yBP (ca. $0.1 \mathrm{~m} \mathrm{y}^{-1}$ at minimum), due to the abrupt decrease of flow caused by water level lowering and changes in stream courses in the upstream lakes (Lewis and Anderson, 1989; Tinkler et al., 1994). The mean recession rate prior to that interval was similar to that after 5,500 yBP (ca. $1.6 \mathrm{~m} \mathrm{y}^{-1}$ ).

Niagara Falls at present consists of several falls, due to diversion of the stream slightly upstream of the site. The largest fall in the western Canadian side, named Canadian or Horseshoe Falls and henceforth referred to as the Horseshoe, has a horizontal curved 
81 762-m-long rim, slightly overhanging face, and a single uninterrupted fall of water with a 51-m height. Another fall at the eastern side, named American Falls, has a relatively straight rim with a length of $335 \mathrm{~m}$. The face of American Falls is nearly vertical but there is no overhang and the lower portion is filled with fallen rock blocks, like talus deposit, for nearly half of its total height of $54 \mathrm{~m}$.

Changes to Niagara Falls during historical times have been recorded in various documents since the $1600 \mathrm{~s}$. The early records were provided simply as artists' pictures, but since the 19th century detailed topographic measurements have been conducted by geologists. Philbrick (1970) gave a detailed summary of the changes in horizontal morphology of Niagara Falls based on the literature, so that we can see the dimensions of the waterfalls in the past (Fig. 2). The lip length of the Horseshoe has increased dramatically as its horizontal shape became progressively more curved over recent centuries, whereas that of the American Falls has merely changed. The height of Niagara Falls has scarcely changed since its formation in the Holocene, as suggested by the constant height of the Great Gorge.

Since the late 19th century, diversion of water to hydroelectric power plants has caused a severe reduction in water flowing over Niagara Falls (Tiplin, 1988). The flow is now regularized to prevent shortages of flowing water for tourists. The changing flow in the river has been documented in the literature (e.g., International Joint Commission, 1953). The presence of Goat Island between Horseshoe and American Falls causes 90\% of the river water to pass over the Horseshoe and 10\% over American Falls.

The recession rate of Niagara Falls, the Horseshoe Falls in particular, has been precisely recorded in the last century (Gilbert, 1907; Philbrick, 1970; Tinkler, 1987). The largest recession rate of the Horseshoe was reported by Gilbert (1907) to be $2.0 \mathrm{~m} \mathrm{y}^{-1}$ in $1875-1905$, whereas the average rate in this period was about $1.3 \mathrm{~m} \mathrm{y}^{-1}$ (International Joint Commission, 1953). The rate has progressively decreased due to the building of power plants during the past century (International Joint Commission, 1953; Table 1), and the current rate is supposed to be less than 
$1070.1 \mathrm{~m} \mathrm{y}^{-1}$ although no certain record is available for the recent recession (Tinkler, 1993, 1994).

108 The rate of recession of American Falls is much less than the Horseshoe. Gilbert (1907)

109 inferred that the recession rate of American Falls had been about $0.1 \mathrm{~m} \mathrm{y}^{-1}$ for hundreds of years.

110 The modern rate is assumed to be of the order of $0.01 \mathrm{~m} \mathrm{y}^{-1}$ (Tinkler, 1993, 1994).

111

\section{Estimating waterfall recession rates from empirical equations}

\subsection{An empirical equation for estimating waterfall recession rates}

To quantify the effects of flow and lip length on the recession rate of Niagara Falls, we use a previously proposed model which estimates the relationship between the waterfall recession rate and relevant physical parameters, namely erosive force and bedrock strength (Hayakawa and Matsukura, 2003a). Supposing that the rate of waterfall recession depends on the erosional force of the stream and the strength of the resisting bedrock, dimensional analysis finds a dimensionless index, $F R$, based on these variables:

$121 \quad F R=\frac{A P}{W H} \sqrt{\frac{\rho}{S_{\mathrm{c}}}}$

where $A\left(\mathrm{~L}^{2}\right)$ is the upstream drainage area of a waterfall; $P\left(\mathrm{~L} \mathrm{~T}^{-1}\right)$ is the mean annual precipitation in the drainage basin, so that the product of $A$ and $P$ accounts for the annual stream flow over the waterfall; $W(\mathrm{~L})$ and $H(\mathrm{~L})$ are the width (lip length) and height of the waterfall, $\rho$ $\left(\mathrm{M} \mathrm{L}^{-3}\right)$ is the water density, and $S_{\mathrm{c}}\left(\mathrm{M} \mathrm{L}^{-1} \mathrm{~T}^{-2}\right)$ is the unconfined compressive strength of bedrock. The dimensionless index FR represents the balance between the erosional force and bedrock resistance as a whole, where all these parameters are given in the SI unit. using data for waterfalls in the Boso Peninsula of eastern Japan gives the following equation (Hayakawa and Matsukura, 2003a): 
$131 \quad E=99.7 F R^{0.73}=99.7\left(\frac{A P}{W H} \sqrt{\frac{\rho}{S_{\mathrm{c}}}}\right)^{0.73}$

This equation has been found to give good order-of-magnitude estimates of waterfall recession rates in many areas (Hayakawa and Matsukura, 2003b; Hayakawa, 2005; Hayakawa and Wohl, 2005; Hayakawa et al., 2005, 2008a), with the exception of rivers carrying abundant transported sediments (Hayakawa et al., 2008b; Hayakawa et al., 2009).

As the proxy of discharge in the $F R$ index, $A$ and $P$ have been individually measured in previous studies, because direct measurement data of the discharge is not available for most waterfalls. Fortunately, the stream discharge has long been measured in the Niagara River. The flow volume of the Niagara is stable in normal conditions, because it depends on the water budget in the Great Lakes, which is too large to be significantly affected by individual storms and other local and short-term climatic events (Tinkler, 1993). For the same reason, estimation of the discharge of the Niagara River from drainage area and precipitation is inappropriate. We therefore use stream discharge, $Q\left(\mathrm{~L}^{3} \mathrm{~T}^{-1}\right)$, for the $F R$ index, instead of the product of $A$ and $P$.

144 Eqs. (1) and (2) become:

$$
145 \quad F R=\frac{Q}{W H} \sqrt{\frac{\rho}{S_{c}}}
$$

146 and

$$
E=99.7 F R^{0.73}=99.7\left(\frac{Q}{W H} \sqrt{\frac{\rho}{S_{c}}}\right)^{0.73}
$$

\subsection{Data acquisition and model applications}

The present water discharge over Niagara Falls is controlled artificially, based on an international agreement between Canada and the US made in 1953. The regulated flow discharge is $2832 \mathrm{~m}^{3} \mathrm{~s}^{-1}$ in summer daytime (0800 to 2200 hours from April 1st to September 
$154 \mathrm{~m}^{3} \mathrm{~s}^{-1}$ ) at all other times. The annual-mean flow discharge at present is therefore $1770 \mathrm{~m}^{3} \mathrm{~s}^{-1}$, 155 which is $30 \%$ of the natural flow level of ca. $5760 \mathrm{~m}^{3} \mathrm{~s}^{-1}$ until a century ago (Tinkler, 1993). The 156 present annual-mean discharge over the Horseshoe is $1593 \mathrm{~m}^{3} \mathrm{~s}^{-1}(90 \%$ of the Niagara River discharge) and that over American Falls is $177 \mathrm{~m}^{3} \mathrm{~s}^{-1}(10 \%)$.

Since water was first diverted through hydroelectric power plants in the late 19th century, the water discharge over the waterfalls was progressively reduced, until the Canada-USA treaty was agreed in 1953. The discharge was reported to be $4147 \mathrm{~m}^{3} \mathrm{~s}^{-1}$ ( $72 \%$ of natural flow) in 1905-1927, and $3456 \mathrm{~m}^{3} \mathrm{~s}^{-1}(60 \%)$ in 1927-1950 (International Joint Commission, 1953). Table 2 summarizes the historical changes of flow volume over Horseshoe and American Falls.

Lip lengths of the Horseshoe in differing years have been obtained by measuring the lengths of its past crest lines on the map by Philbrick (1970), on which the development of the shape of Niagara Falls is well documented (Fig. 2). Lines based on topographic measurement surveys have been available since 1678 , but only the lines after 1819 are used because the left end of the lines in 1678 and 1764 are unclear. The lip length of the Horseshoe has increased in recent times from $420 \mathrm{~m}$ in 1842 to $762 \mathrm{~m}$ in 2000 as the profile becomes more curved (Table $3)$.

To estimate the intact rock strength of the waterfalls, Schmidt hammer (N-type) measurements were made using the repeated impact method, which involves averaging over 20 impacts at each point after eliminating outliers (Hucka, 1965; Matsukura and Tanaka, 2000; Matsukura and Aoki, 2004). Since the waterfall consists of two major different rock layers, dolomite and shale, the Schmidt hammer rebound values, $R_{\mathrm{N}}(\%)$, of both rocks are measured at several locations around the waterfall. The rocks close to the waterfall are generally fresh, but those exposed along the walls of the Great Gorge are commonly weathered, probably by freeze-thaw processes. The measured Schmidt hammer rebound values are summarized for each rock type and weathering conditions in Table 4. Although the dolomite layer along the Gorge, forming the caprock structure of the waterfall, has been considered to be much harder than the 
shale layer, no significant differences were found between dolomite and shale, whereas

181 differences were much clearer between fresh and weathered conditions (Table 4). The Schmidt

182 hammer rebound values may include the effects of joints or anisotropy of the bedding planes in the shale at least to some extent, because the bedding spacing is small enough (several centimeters) to be reflected in the rebound values. We then use average values for the fresh rocks in calculating the unconfined compressive strength for the $F R$ index, because rocks under flowing water should be fresh and their strength is directly related to the erosion of the waterfall. The Schmidt hammer rebound values are then converted to the unconfined compressive strength $S_{\mathrm{c}}(\mathrm{MPa})$ using the Schmidt hammer equipment conversion equation $\left(\log \left(S_{\mathrm{c}} / 0.098\right)=0.0307\right.$ $\left.R_{\mathrm{N}}+1.4016\right)$.

By substituting the parameter values for the Horseshoe into Eq. (4), the present recession rate is estimated to be $0.15 \mathrm{~m} \mathrm{y}^{-1}$. The past recession rates of the Horseshoe were also computed for the following six intervals: 1842-1875 (H1), 1875-1905 (H2), 1905-1927 (H3), 1927-1950 (H4), 1950-2000 (H5) and 2000- (H6). These have differing discharge and lip length values, and the recession rates varied from 0.15 to $0.55 \mathrm{~m} \mathrm{y}^{-1}$ (Table 5).

The present recession rate of American Falls is estimated to be $0.05 \mathrm{~m} \mathrm{y}^{-1}$ with the regulated flow (A2, Table 5). Assuming that the lip length, height and rock strength have not changed, the recession rate of American Falls in the past, i.e., under the natural conditions prevailing until a century ago (-1905), is estimated to be $0.13 \mathrm{~m} \mathrm{y}^{-1}$ (A1, Table 5).

\section{Discussion and conclusions}

The estimated recession rates of the Horseshoe during the last century $\left(0.15-0.53 \mathrm{~m} \mathrm{y}^{-1}\right)$ are of the same order as the actual recession rates $\left(0.1-1.2 \mathrm{~m} \mathrm{y}^{-1}\right)$. The estimated recession rates of American Falls $\left(0.05-0.12 \mathrm{~m} \mathrm{y}^{-1}\right)$ are also in good agreement with the actual recession rates $\left(0.01-0.1 \mathrm{~m} \mathrm{y}^{-1}\right)$. Agreement is also found in the relationships between the temporally shifting 
FR and the actual recession rates of the Horseshoe and American Falls, in which all the data for

207 each period are plotted around the line of Eq. (4) (Fig. 3). The Niagara River transports almost

208 no sediment, because it is trapped upstream in the Great Lakes. Therefore, the results obtained

209 for Niagara Falls support the validity of Eq. (4), which has been applied to waterfalls in

210 detachment-limited rivers with less sediment (e.g., Hayakawa and Matsukura, 2003a,b;

211 Hayakawa et al., 2008b).

212 The present model gives the best results when changes in both water discharge and

213 waterfall width are incorporated into the equation. If discharge is recovered to the past natural

214 level, the model equation predicts the recession rate at the Horseshoe with the current shape to

215 increase to $0.4 \mathrm{~m} \mathrm{y}^{-1}$; whereas, if the discharge had not been reduced for the past hundred years

216 and only the lip length changed, the present recession rate at the Horseshoe would be $0.3 \mathrm{~m} \mathrm{y}^{-1}$.

217 These expected rates with changes in either discharge or width alone are relatively apart from

218 the actual recession rate. This implies that the reduction of flow discharge due to water

219 diversion though hydroelectric power plant is not the only reason for the reduced recession rate

220 at the Horseshoe; the natural change of its shape is also important. The lip length of American

221 Falls, in contrast, has scarcely changed, and the reduction of discharge is sufficient to explain

222 the decreased recession rate of the waterfall. This observation supports the qualitative argument

223 by Philbrick (1970) that the decreased Horseshoe recession rate is due to both the flow

224 reduction and changes in its horizontal curved shape causing stress dispersion. Philbrick (1970)

225 emphasizes that the presence of notches in the plan lip form is a major factor causing instability

226 enhancing erosion. The effect of such plane shape is not incorporated in the FR index. A distinct

227 notch along the lip of the Horseshoe existed earlier (H1 to H4) but disappeared recently (H5 and

228 H6). This may explain the overestimation of the recession rate for $\mathrm{H} 5$ and $\mathrm{H} 6$ and

229 underestimation for $\mathrm{H} 1$ to H4 (Fig. 3). In contrast, the data for American Falls are less apart

230 from the line in Fig. 3, prpbably because the shape of American Falls has not changed abruptly

231 throughout the last centuries without distinct notches nor curved lip. 
Further studies on recession rates of Niagara Falls in the Holocene and the 233 palaeoenvironments of the surrounding area are necessary in relation to the long-term changes 234 in the parameters incorporated in the $F R$ index as well as the other factors such as waterfall plan 235 shape. The mechanisms of erosion of Niagara Falls also remain uncertain, and the classical 236 caprock model for waterfall erosion (Gilbert, 1907) should be reassessed because the dolomite 237 and shale layers have similar rock strengths, and undercutting of waterfall face is not common to many waterfalls (Young, 1985; Lamb et al., 2007).

\section{Acknowledgements}

247 This research is supported in part by a Grant-In-Aid for JSPS Fellows from the Ministry of 248 Education, Science, Sports and Culture of the Japanese Government (19-2271). Ellen Wohl and 249 an anonymous reviewer provided valuable comments on a previous version of the manuscript. 250 We also thank Takashi Oguchi for his help in improving the paper. 
Barnes, H.L., 1956. Cavitation as a geological agent. American Journal of Science 254, 493-505.

Begin, Z.B., Meyer, D.F., Schumm, S.A., 1980. Knickpoint migration due to baselevel lowering. Journal of Waterway Port Coastal and Ocean Division, ASCE 106, 369-388.

Bishop, P., Goldrick, G., 1992. Morphology, processes and evolution of two waterfalls near Cowra, New South Wales. Australian Geographer 23, 116-121.

Bishop, P., Hoey, T.B., Jansen, J.D., Artza, I.L., 2005. Knickpoint recession rate and catchment area: the case of uplifted rivers in eastern Scotland. Earth Surface Processes and Landforms $30,767-778$.

Crosby, B.T., Whipple, K.X., 2005. Knickpoint initiation and distribution within fluvial networks: 236 waterfalls in the Waipaoa River, North Island, New Zealand. Geomorphology 82, 16-38.

Derricourt R.M., 1976. Retrogression rate of the Victoria Falls and the Batoka Gorge. Nature $264,23-25$.

Ford, D.C., 1968. Waterfalls. In: Fairbridge, R.W. (Ed), The Encyclopedia of Geomorphology, Reinhold Book Corporation, New York, pp. 1219-1220.

Gilbert, G.K., 1907. Rate of recession of Niagara Falls. U.S. Geological Survey Bulletin 306, $1-31$.

Hayakawa Y., 2005. Reexamination of a predictive equation of waterfall recession rates in Boso Peninsula, Chiba Prefecture, Japan. Geographical Review of Japan 78, 265-275.

Hayakawa Y., Matsukura Y., 2002. Recession rates of waterfalls: a brief review. Annual Report of Institute of Geoscience, University of Tsukuba 28, 1-4.

Hayakawa, Y., Matsukura, Y., 2003a. Recession rates of waterfalls in Boso Peninsula, Japan, and a predictive equation. Earth Surface Processes and Landforms 28, 675-684. 
Hayakawa, Y., Matsukura, Y., 2003b. Recession rates of Kegon Falls in Nikko, Tochigi Prefecture, Japan. Journal of Geography (Tokyo) 112, 521-530. (in Japanese with English abstract).

Hayakawa, Y.S., Oguchi, T., 2006. DEM-based identification of fluvial knickzones and its application to Japanese mountain rivers. Geomorphology 78, 90-106.

Hayakawa, Y.S., Oguchi, T., 2009. GIS analysis of fluvial knickzone distribution in Japanese mountain watersheds. Geomorphology, in press.

Hayakawa, Y.S., Wohl, E.E., 2005. Recession rate of Poudre Falls in Rocky Mountain Front Range, Colorado, USA. Geographical Review of Japan 78, 853-858.

Hayakawa, Y.S., Yokoyama, S., Matsukura, Y., 2005. Recession rates of waterfalls in and upstream of the Tateno Canyon, Aso Volcano. Transactions, Japanese Geomorphological Union 26, 439-449 (in Japanese with English abstract).

Hayakawa, Y.S., Yokoyama, S., Matsukura, Y., 2008a. Erosion rates of waterfalls in post-volcanic fluvial systems around Aso volcano, southwestern Japan. Earth Surface Processes and Landforms 33, 801-812.

Hayakawa, Y.S., Obanawa, H., Matsukura, Y., 2008b. Post-volcanic erosion rates of Shomyo Falls in Tateyama, central Japan. Geografiska Annaler 90A, 65-74.

Hayakawa, Y.S., Matsuta, N., Matsukura, Y., 2009. Rapid recession of fault-scarp waterfalls: Six-year changes following 921 Chi-Chi Earthquake in Taiwan. Transactions, Japanese Geomorphological Union 30, in press.

Hucka, V., 1965. A rapid method of determining the strength of rocks in situ. International Journal of Rock Mechanics and Mining Sciences 2, 127-134.

International Joint Commission, 1953. Report on the Remedial Works Necessary to Preserve and Enhance the Scenic Beauty of the Niagara Falls and River. International Joint Commision, Washington, DC.

Kukal Z., 1990. The rate of geological processes. Earth Science Reviews 28, 1-258. 
Lamb, M.P., Howard, A.D., Dietrich, W.E., Perron, J.T., 2007. Formation of amphitheater-headed valleys by waterfall erosion after large-scale slumping on Hawai'i. Geologcial Society of America Bulletin, 119, 805-822.

Lewis, C.F., Anderson, T.W., 1989. Oscillations of levels and cool phases of the Laurentian Great Lakes caused by inflows from glacial Lakes Aggasiz and Barlow-Ojibway. Journal of Paleolimnology 2, 99-146.

Matsukura, Y., Aoki, H., 2004. The Schmidt hammer: a brief review and some problems in geomorphology. Transactions of the Japanese Geomorphological Union 25, 175-196 (in Japanese with English abstract).

Matsukura, Y., Tanaka, Y., 2000. Effect of rock hardness and moisture content on tafoni weathering in the granite of Mount Doeng-Sung, Korea. Geografiska Annaler 82A, $59-67$.

Pasternack, G.B., Ellis, C.R., Leier, K.A., Vallé, B.L., Marr, J.D., 2006. Convergent hydraulics at horseshoe steps in bedrock rivers. Geomorphology, 82, 126-145.

Philbrick, S.S., 1970. Horizontal configuration and the rate of erosion of Niagara Falls. Geological Society of America Bulletin 81, 3723-3732.

Spencer, J.W.W., 1907. The Falls of Niagara, Their Evolution and Varying Relation to the Great Lakes. Department of Mines and Surveys, Geological Branch, Ottawa.

Tinkler, K., 1987. Niagara Falls 1750-1845: The idea of a history and the history of an idea. Geomorphology 1, 69-85.

Tinkler, K.J., 1993. Field Guide Niagara Peninsula and Niagara Gorge. Third International Geomorphology Conference, McMaster University, Hamilton, Ontario, Canada, 24p.

Tinkler, K.J., 1994. Entre Lacs: A postglacial peninsula physiography. In: Gayler, H.J. (Ed.), Niagara's Changing Landscapes, Carleton University Press, Ottawa, Canada, 13-51.

Tinkler, K.J., Pengelly, J.W., Parkins, W.G., Asselin, G., 1994. Postglacial recession of Niagara Falls in relation to the Great Lakes. Quaternary Research 42, 20-29. 
Tiplin, A.H., 1988. Our Romantic Niagara: A Geological History of the River and the Falls. The Niagara Falls Heritage Foundation, Niagara Falls, Ontario, Canada, 216 p.

Whipple, K.X., Hancock, G.S., Anderson, R.S., 2000. River incision into bedrock: Mechanics and relative efficacy of plucking, abrasion, and cavitation. Geological Society of America Bulletin 112, 490-503.

Wohl, E.E., 1998. Bedrock channel morphology in relation to erosional processes. In: Tinkler, K.J., Wohl, E.E. (Eds.), Rivers over Rock, American Geophysical Union, Washington, DC, pp. 133-151.

Wohl, E.E., 2000. Mountain Rivers. American Geophysical Union, Washington, DC.

Young, R.W., 1985. Waterfalls: form and process. Zeitschrift für Geomorphologie Supplementband 55, 81-95.

von Engeln, O.D., 1940. A particular case of Knickpunkte. Annals of American Geographers 30, $268-271 ; 281-284$. 
348 Table 1. Actual recession rates of Horseshoe Falls and American Falls over differing time periods.

\begin{tabular}{lllll}
\hline \multirow{2}{*}{ Duration } & \multicolumn{3}{c}{ Recession rate } \\
& & $E\left(\mathrm{~m} \mathrm{y}^{-1}\right)$ & Source \\
\hline Horseshoe Falls $1842-1875$ & $(\mathrm{H} 1)$ & $1.2-1.3$ & Gilbert, 1907; International Joint Commission, 1953 \\
& $1875-1905$ & (H2) & $1.3-2.0$ & Gilbert, 1907; International Joint Commission, 1953 \\
& $1905-1927$ & (H3) & 0.98 & International Joint Commission, 1953 \\
& $1927-1950$ & (H4) & 0.67 & International Joint Commission, 1953 \\
& $1950-2000$ & (H5) & 0.1 & Tinkler, 1993, 1994 \\
& Modern & (H6) & 0.1 & Tinkler, 1993, 1994 \\
\hline American Falls & 500 y (-1905) (A1) & 0.098 & Gilbert, 1907 \\
& Modern & (A2) & 0.01 & Tinkler, 1993, 1994 \\
\hline
\end{tabular}


353 Table 2. Historical changes in flow discharge over Niagara Falls.

\begin{tabular}{cccc}
\hline Duration & $\begin{array}{c}\text { Discharge over } \\
\text { Niagara Falls }\left(\mathrm{m}^{3} \mathrm{~s}^{-1}\right)\end{array}$ & $\begin{array}{c}\text { Discharge over } \\
\text { Horseshoe Falls }\left(\mathrm{m}^{3} \mathrm{~s}^{-1}\right)\end{array}$ & $\begin{array}{c}\text { Discharge over } \\
\text { American Falls }\left(\mathrm{m}^{3} \mathrm{~s}^{-1}\right)\end{array}$ \\
\hline \multirow{3}{1}{$\begin{array}{l}(100 \%) \\
1942-1905\end{array}$} & 5760 & $(90 \%)$ & $(10 \%)$ \\
$1905-1927$ & 4147 & 5184 & 576 \\
$1927-1950$ & 3456 & 3732 & 415 \\
354 & 1770 & 3110 & 346 \\
& $1950-$ present & 1593 & 177 \\
\hline
\end{tabular}

355

356 
357 Table 3. Historical changes in lip length of Horseshoe Falls.

\begin{tabular}{ccc} 
& Year & Lip length (m) \\
\cline { 2 - 3 } & 1819 & 473 \\
& 1842 & 420 \\
1875 & 501 \\
& 1886 & 586 \\
& 1890 & 614 \\
& 1927 & 626 \\
& 1964 & 723 \\
358 & 2000 & 762 \\
\hline
\end{tabular}

359 
360 Table 4. Schmidt hammer rebound values $\left(R_{\mathrm{N}}\right)$ averaged for each rock type and weathering condition. Numbers in parentheses show the standard deviation.

\begin{tabular}{lcc}
\hline & \multicolumn{2}{c}{ Condition } \\
\cline { 2 - 3 } & Fresh & Weathered \\
\hline Dolomite & $53.4(4.7)$ & $31.7(4.0)$ \\
Shale/Mudstone & $51.3(3.4)$ & $29.7(1.4)$ \\
\hline Average & 52.3 & 30.7 \\
\hline
\end{tabular}

362

363 
364 Table 5. Summary of data for parameters giving the $F R$ index and FR-based waterfall recession rates, where $Q$ is discharge, $W$ is lip length of waterfall, $H$ is height of waterfall, $R_{\mathrm{N}}$ is Schmidt hammer rebound value of bedrock, and $S_{\mathrm{c}}$ is unconfined compressive strength of bedrock converted from $R_{\mathrm{N}}$. The modern lip length and height of the waterfalls are given by Niagara Falls State Park, NY.

\begin{tabular}{|c|c|c|c|c|c|c|c|c|}
\hline Waterfall & Duration & $\begin{array}{c}Q \\
\left(\mathrm{~m}^{3} \mathrm{~s}^{-1}\right)\end{array}$ & $\begin{array}{l}W \\
(\mathrm{~m})\end{array}$ & $\begin{array}{l}H \\
(\mathrm{~m})\end{array}$ & $\begin{array}{l}R_{\mathrm{N}} \\
(\%)\end{array}$ & $\begin{array}{c}S_{\mathrm{c}} \\
(\mathrm{MPa})\end{array}$ & $\begin{array}{c}F R \\
\times 10^{3}(-)\end{array}$ & $\begin{array}{c}\text { Computed rate } \\
\left(\mathrm{m} \mathrm{y}^{-1}\right)\end{array}$ \\
\hline \multirow{6}{*}{ Horseshoe Falls } & 1842-1875 (H1) & 5184 & 420 & 51 & 52.3 & 99.7 & 0.766 & 0.53 \\
\hline & $1875-1905(\mathrm{H} 2)$ & 5184 & 501 & 51 & 52.3 & 99.7 & 0.643 & 0.47 \\
\hline & 1905-1927 (H3) & 3732 & 614 & 51 & 52.3 & 99.7 & 0.377 & 0.32 \\
\hline & $1927-1950(\mathrm{H} 4)$ & 3110 & 626 & 51 & 52.3 & 99.7 & 0.309 & 0.27 \\
\hline & $1950-2000$ (H5) & 1593 & 723 & 51 & 52.3 & 99.7 & 0.137 & 0.15 \\
\hline & $2000-$ & 1593 & 762 & 51 & 52.3 & 99.7 & 0.130 & 0.15 \\
\hline \multirow[t]{2}{*}{ American Falls } & -1905 & 576 & 335 & 54 & 52.3 & 99.7 & 0.101 & 0.12 \\
\hline & Modern & 177 & 335 & 54 & 52.3 & 99.7 & 0.031 & 0.05 \\
\hline
\end{tabular}


373 Fig. 1. Study site. Niagara Falls at present comprises two major falls, Horseshoe Falls and American Falls.

375 Fig. 2. Historical changes of the plan shape of Horseshoe Falls (after Philbrick, 1970).

376 Fig. 3. Relationships between the calculated FR values and actual recession rates for the Horseshoe (solid circle) and American Falls (solid triangle). The suffix for each plot (H1 H6 and A1 A2) corresponds to each durations shown in Tables 1 and 5. Translucent arrows indicate time direction. 

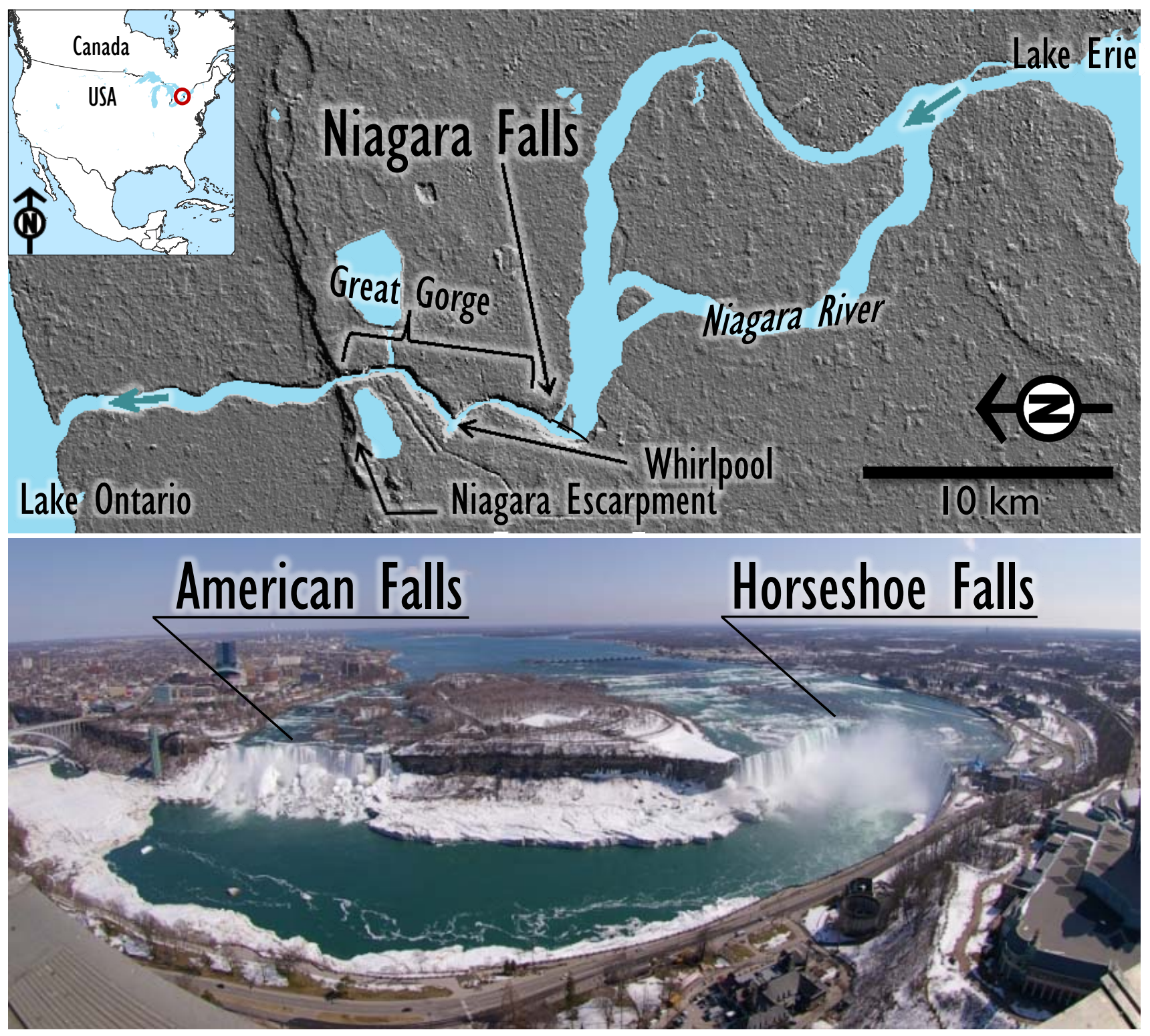

Figure 1. 


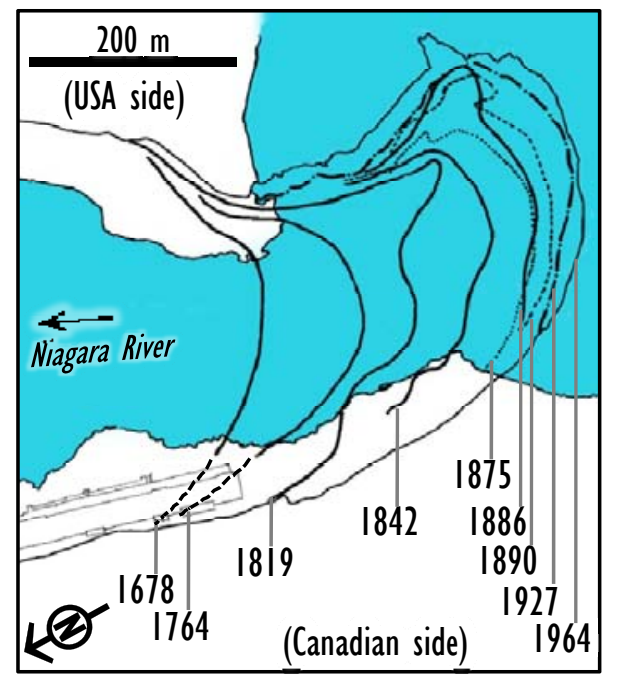

Figure 2. 


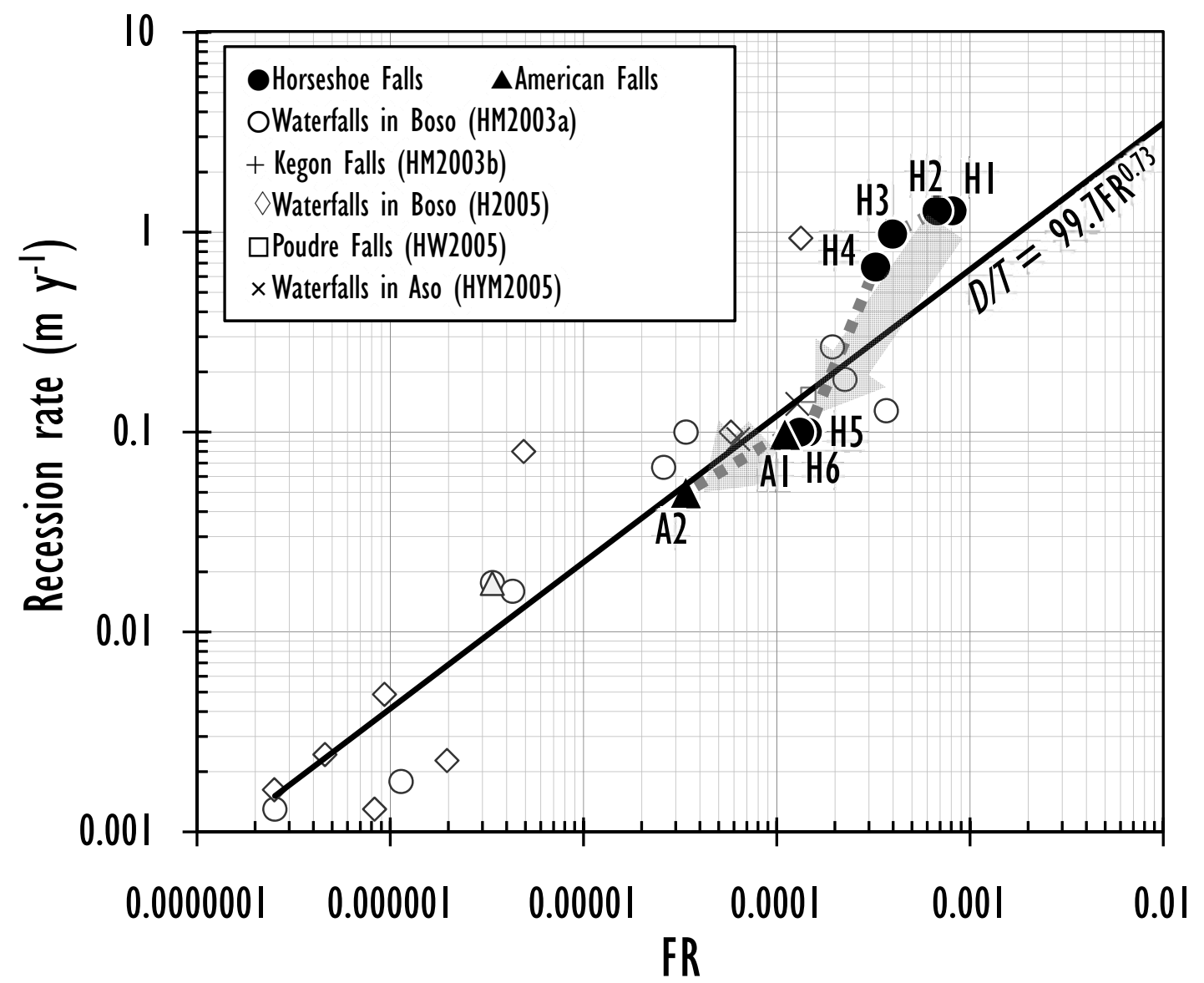

Figure 3. 